\title{
Short-term Fiscal Sustainability of V4 Countries
}

\author{
Marianna Sávai*
}

\begin{abstract}
:
The financial crisis placed budget and fiscal policy sustainability on the centre stage of researches. Recently, a number of studies have suggested that the researcher should take use of the simplest models, because they provide accurate forecasting results. This present study falls in line with this new research direction, follows a simple intertemporal budget constraint, calculates primary gap in some selected years $(2004,2009,2014)$ and tests assumptions for short-term in Visegrad Group Countries. Results indicate that the fiscal stance of V4 countries was varied. In most of the examined years, the fiscal policy of the countries have seemed to be unsustainable, which pointed out the fact that the fiscal controls are need to be strengthened in short- and long-term too.
\end{abstract}

Key words: Fiscal sustainability; Primary gap; Public debt; V4 countries.

JEL classification: E620.

\section{Introduction}

Nowadays, sustainability and sustainable growth are often mentioned together. In connection with the financial crisis ${ }^{1}$, the budgetary, fiscal policy and sustainability has been in the forefront of research. Based on the definition of fiscal sustainability is very difficult to understand. The study used a boarder scope in understanding this concept: 'concept of fiscal sustainability relates to a government's ability to indefinitely maintain the same set of policies while remaining solvent' (Burnside 2005, p. 10).

It is hard for researchers to analyse the fiscal sustainability, because there is no simple questions regarding this topic. The different methodologies create an analytical framework which is capable of forecasts based on current conditions. Empirical studies about fiscal sustainability have been written in many counties or groups of countries. The aim of this study is to examine fiscal sustainability of Visegrad Group Countries (V4) with review of literature and a simple model what was used by Aristovnik - Berčič (2007).

Visegrad Group Countries means Czech Republic, Hungary, Poland and Slovakia. Declaration $^{2}$ on Cooperation between the Czech and Slovak Federal Republic, the

* Marianna Sávai; University of Szeged, Finance and International Economic Relationships Institute, Kálvária 1, Szeged, Hungary, <savai.marianna@eco.u-szeged.hu>.

1 Global financial crisis effects were not examined by recent study.

2 'A favourable basis for intensive development of cooperation is ensured by the similar character of the significant changes occurring in these countries, their traditional, historically shaped system 
Republic of Poland and the Republic of Hungary in Striving for European Integration signed in Visegrád on 15 February 1991.

The paper is organized as follows: Chapter 2 gives the theoretical background where literature about fiscal sustainability is summarized and some macroeconomic connection factors in Visegrad Group Countries are examined. Chapter 3 deals with the methods of the empirical examination of the current study. Chapter 4 includes data and results by emprical examination and the last Chapter 5 constitutes the Conclusion.

\section{Theoretical Background}

The literature defined the concept of fiscal sustainability from a multiple point of view. The first approach for fiscal sustainability threshold was defined by Buiter (1985) or Blanchard (1990). They said that the fiscal policy is sustainable if debt to GDP ratio is stable. Stable means a long run stability. The following parts of the research summarize the author's claims on the subject.

\subsection{General facts about fiscal sustainability}

Barro (1979) examines empirical data in the U.S, and finds that a positive effect on contemporary debt issue increases in government spending (as in wartime) a countercyclical response of debt to temporary income movements, and a one-toone effect of expected inflation on nominal debt growth.

Bohn (1998) defined a new intertemporal budget constraint in U.S. fiscal data, and shows that an estimated positive response of primary surpluses to the debt GDP ratio and demonstrated that the frequent primary budget deficits do not provide convincing evidence against sustainability, because at low interest rates, a variety of sustainable policies will display primary deficits on average and potentially for long periods.

According to the European Commission's Fiscal Sustainability Report, 'sustainability of fiscal policies is the ability to continue now and in the future, the current policies without change regarding public services and taxation, without causing the debt to rise continuously as a share to GDP' (European Commission 2012, p. 17). In Euro Zone, fiscal sustainability threshold is defined debt to GDP ratio of $60 \%$ by Stability and Growth Pact (SGP), but after the financial crisis the average of debt ratio is much higher than $60 \%$ and continued the growth, $92.1 \%$ in

of mutual contacts, cultural and spiritual heritage and common roots of religious traditions. The diverse and rich cultures of these nations also embody the fundamental values of the achievements of European thought. The mutual spiritual, cultural and economic influences exerted over a long period of time, resulting from the fact of proximity, could support cooperation based on natural historical development' (Declaration, 1991, p. 1). 
2014 based on Eurostat. From this, the researchers and analysts should reflect on the threshold of rethinking in models.

Menguy (2008) draws attention to the fact that SGP has a disadvantage that it concentre on a uniform short-term criterion for the budgetary situation of the European countries (i.e. the current budgetary deficit) although the long run solvability is more important. So he suggests a new budgetary rule, which bear in mind the long run sustainability of the public indebtedness and inspire EU countries to manage healthy budgetary policies in good times so that they protect more leeway in bad times, in spite of inefficient and pro-cyclical policies.

According to IMF the anchor for fiscal policy of 60 percent of GDP is relatively close to the most recent estimates of long-run debt levels for both advanced economies and emerging economies (Cottarreli - Moghadam, 2011). However, he declares that it should not be stick to this reference value, researchers should look at a variety of special circumstances and based on their information to assess the fiscal sustainability of a country.

\subsection{Macroeconomic background of V4}

V4 countries defined transition economies ${ }^{3}$ too, because they were members the former Soviet Union until 1990. V4 countries became independent in 1989/1990 and begun a long transition process what means liberalization, macroeconomic stabilization, restructuring and privatization and legal and institutional reforms (IMF, 2000). Their deep changes are much more difficult and time-consuming because they involve structural reforms and require a major modification of attitudes, incentives, and relationships Policymakers must face large fiscal deficits and macroeconomic problems, they become a more fundamental problem when they force governments to renege on their legal contracts by sequestering or freezing payments across the board (Tanzi, 1999).

Countries that adapted complex fiscal policies were successful in contrast their inflation stabilization programs were less effective, have experienced a faster recovery of growth, without output is fallen sharply. Countries floated their exchange rate, but there are both floating and peg arrangements amid the successful stabilizers (Budina - Wijnbergen, 1997). Countries joined to European

3 Transition economies in Europe and the former Soviet Union: Albania, Bulgaria, Croatia, Czech Republic, FYR Macedonia, Hungary, Poland, Romania, Slovak Republic, Slovenia, Estonia, Latvia, Lithuania and Armenia, Azerbaijan, Belarus, Georgia, Kazakhstan, Kyrgyz Republic, Moldova, Russia, Tajikistan, Turkmenistan, Ukraine, Uzbekistan. Transition economies in Asia: Cambodia, China, Laos, Vietnam (IMF, 2000). 
Union in 2004 focus on new members ${ }^{4}$ and SGP criterions and emphasize that there are large differences in the starting fiscal positions of the new members.

After the EU accession of the V4 countries, a powerful process of indebtedness in foreign currency was launched, mainly in Hungary and Poland, where demand of debt securities increased by non-residents (Fig. 1). Not only has increased the retail lending dramatically in the foreign currency holdings, but also a substantial increase in government debt was experienced. In pre-crisis era the domestic credit booms accelerated by the substantial capital imports (Kovács, 2009, Árvai et al., 2009), which was due to harmonized monetary goals and floating currency regime, underdeveloped capital markets, poor savings accumulation and over-concentrated banking system (Farkas, 2011).

\section{Fig. 1: Debt securities held by nonresidents, 2001-2014 (Million US dollar)}

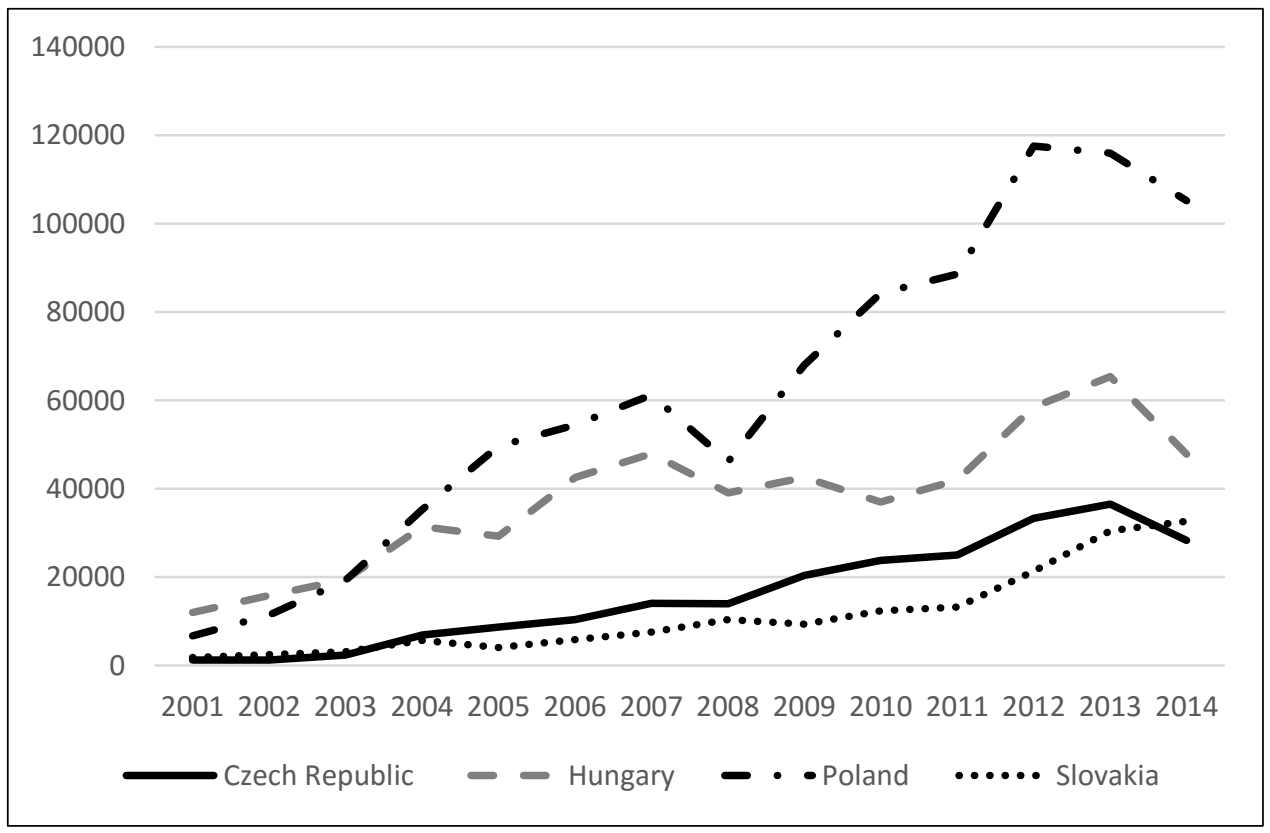

Source: World Bank Database.

Despite the relatively strong and stable CEE-EUR exchange rate, common movements failed to provide credits in a safe haven currency such as CHF. Furthermore, market panic-driven liquidity inflows appreciated the currency and the previously strong correlation temporarily diminished crisis. This phenomena affected financial stability too (Kiss - Schuszter 2015).

4 New members means countries who joined European Union in 2004, Cyprus, Czech Republic, Estonia, Hungary, Latvia, Lithuania, Malta, Poland, Slovenia, Slovakia. 
Despite the success of the transition process some differences between old and new members of European Union remained the same (Orban-Szapary 2004). Fig. 2 shows government debt data in V4 countries and European Union and European Union (EU) 15 countries $^{5}$ (EU-15) averages. No more differences between two EU averages, all EU averages are a little bit lower than EU-15 averages, only data available until 2000. The highest data have Hungary from V4 countires, but in period 2000-2005, debt of V4 countries were under the EU averages, during this period, transition economies' convergence became stronger (Veugelers - Mrak, 2009)

\section{Fig. 2: General government consolidated gross debt in V4 Countries and European Union, 1996-2017 (Percentage of GDP)}

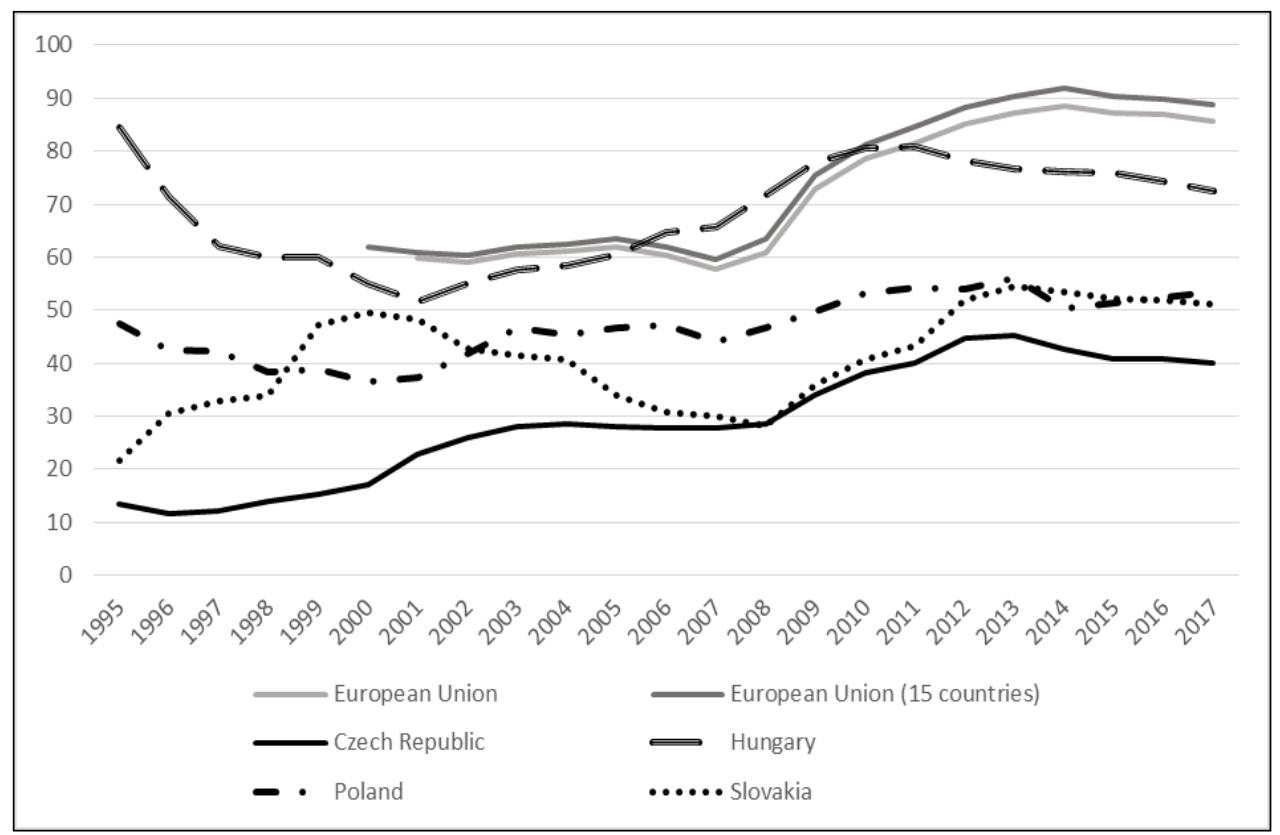

Source: AMECO Database.

In this paper the focus is especially on only intertemporal budget constraint, but it also underlines the most important elements of long run fiscal sustainability, which are pension payment obligations and health care outlays for the elderly due to population ageing and the current fertility rate (Orban-Szapary, 2004, McHugh et al, 2011). It is important that fiscal policies have been driven by political factors, this connention is examined for example by Roubini and Sachs (1989),

5 EU 15 countries means Austria, Belgium, Denmark, Finland, France, Germany, Greece, Ireland, Italy, Luxembourg, the Netherlands, Portugal, Spain, Sweden and the United Kingdom. 
Alesina et al (1996), Wyplosz (2007), Mauro et al (2015). During the last decade, fiscal councils ${ }^{6}$ are established in some countries, for example in Hungary, but due to space limitations, we do not deal with this in the current study.

\section{Methods}

According to Wyplosz (2007) we could not apply sophisticated forecasting methods, because sustainability depends on the future so we could not draft a statement with high security about primary surpluses. Solvency, and therefore sustainability as it builds upon solvency, is entirely forward-looking. It is future balances that matter, not the past and not just the current debt level. Based on the difficult and sophisticated models' needs, huge data demands the paper to focus on clear and simple indices, what easily interpreted, suggested by Blanchard et al (1990) and Cruz-Rodríguez (2014).

Indicators for measuring fiscal sustainability are very different. One of the traditional indicators is debt to GDP ratio, it has been used Buiter (1985) and Blanchard (1990), Fatas - Mihov (2009), and nowadays D'Erasmo (2015). Blanchard calculates the 'tax gap', which is the change in the tax ratio that would be necessary to stabilize the current debt-to-GDP ratio. Barta (2015) emphasizes that 'tax gap' is not equal to a primary gap, because primary gap measured the current interest and growth rates may still menaced solvency if interest rates go up and/or growth rates plunge. Primary gap indicators can be analyse and explain easily, because they represent how painful the adjustment would need to be to stabilize the debt today.

Kotosz - Peak (2013) used a two-equation VAR model to estimate a mixed theoretical model (Keynesian and Lucasian) on Hungarian data between 1960 and 2011. They found that results was influenced by in several aspects of both short and long term implications, and in terms of criteria for stability. They showed that stability is possible, but it requires sticking to a defined expenditure/GDP ratio, otherwise consolidations will unavoidably hurt growth.

Spaventa (1987) pronounce the condition about primary gap indicators. There are neither necessary nor sufficient for the sustainability of fiscal policies. A country will have a sustainable fiscal regime if current and future primary balances,

6 Fiscal council 'stands for such a new, smaller or bigger body (consisting of a minimum of three members but could incorporate as many as two dozen) the members of which are people of high professional prestige who are independent from the government or the national assembly, operating with a background of analytical capacities that enable them to prepare alternative evaluations, forecasts or technical projections versus the macroeconomic calculations and forecasts of the government and, thanks to their respect, are also able to assert their opinions' (Kovacs, 2014, p. 338). 
interest rates, and growth rates, are such that the government's intertemporal budget constraint is satisfied (Drudi - Prati, 2000).

Buiter (1985) stressed two additional weaknesses of the one-period primary gap indicator. The one of the drawbacks of this indicator is that actual current primary fiscal balance could be affected by cyclical increases or reductions in public sector revenues and/or expenditures. The other drawback is that the current nominal interest rate and growth of nominal GDP may be unrepresentative of their respective long-term expected average values.

The tax gaps indicies, are based on a comparison of the current debt-GDP ratio and that $\mathrm{n}$ periods ahead with given fixed values of the deficit and discount rate (Polito - Wickens, 2012).

More recently, the European Commission (2006) has formulated two fiscal indicators: S1 and S2. Both are based on official projections of government expenditure that include the effects of population ageing. The $\mathrm{S} 1$ indicator is just the Maastricht condition that maximum debt should be $60 \%$ of GDP, while the S2 indicator requires that the government inter-temporal budget constraint be satisfied over an infinite horizon. European Commission (2009, 2012) modified S1 and S2 indicators methods, that to further promote sustainability measurement..

Aristovnik - Berčič (2007) examined transition economies with a specific intertemporal budget constraint. The study follow this methodology with some modification. The reason for changes that my paper not examine long-term sustainability, because there are too many uncertain factors in this time horizon and their enumeration exceeds length limit.

Fiscal primary gap defined the difference between the actual fiscal primary balance and the primary balance required to stabilize the debt to GDP ratio (Aristovnik - Berčič, 2007).

According to IMF (2002), solvency only necessary not sufficient assumption fiscal sustainability but a non-increasing government debt to GDP ratio is a practical sufficient condition for sustainability. Probably, the government remain solvent as long as the GDP ratio is not growing. Hemming and MacKenzie (1991) the (shortterm) budget constraint is:

$$
\Delta D_{t} / Y_{t}=\left(r_{t}-g_{t}\right) D_{t-1} / Y_{t}+B_{t} / Y_{t}+R_{t} / Y_{t}
$$

where $D_{t}$ is total public debt, $Y_{t}$ is nominal GDP, $r_{t}$ represents the real interest rate sector and $g_{t}$ the real economic growth rate, $B_{t}$ is nominal primary (negative) balance of the public sector, in study empirical means the gap between noninterest expenditure and total revenue and $R_{t}$ residual factor. When $r_{t}>g_{t}$ this signed upward pressure on the debt/GDP ratio, while $r_{t}<g_{t}$ indicates downward pressure. The remaining part of the right-hand area show the non-interest flows of government. If it is negative, government generates a primary surplus, involve the 
debt/GDP ratio is decreasing. If it is positive, government give rise to a primary deficit, consequently the debt/GDP ratio is increasing (Aristovnik - Berčič, 2007, p. 6).

If the debt/GDP ratio depends on the relationship between the interest rate (r), and the economic growth rate (g), we can use (2) and (3) formula.

First can be presented as if $g>r$ :

$$
D_{t} / Y_{t}=-b\left(\frac{1+g}{g-r}\right)
$$

Second as if $r>g$ :

$$
D_{t} / Y_{t}=-b\left(\frac{1+g}{g-r}\right)\left(\frac{1+r}{g+r}\right)^{t}+b\left(\frac{1+g}{g-r}\right)+\left(\frac{1+r}{g+r}\right)^{t} D_{0} / Y_{0}
$$

where $b=\mathrm{Bt} / \mathrm{Yt}$ is primary deficit a constant ratio of GDP, the long-term public deficit ratio is not constant.

The (un)sustainability position, which can be measured as

$$
\left|-b\left(\frac{1+g}{g-r}\right)\right|>\left|D_{0} / Y_{0}\right|
$$

Sustainable primary surplus, which can be demonstrated as

$$
-B_{t} / Y_{t}=\left(r_{t}-g_{t}\right) D_{t-1} / Y_{t}
$$

Although this study did not calculate, but can measure the medium-term and longterm tax gaps (Blanchard, 1990) and the sustainable conventional public balance needs alternative indicator, which sustainable budget deficit (GOVBt) is derived from equation (5) and equals the growth rate multiplied by the debt ratio:

$$
-G O V B_{t} / Y_{t}=\left(r_{t}-g_{t}\right) D_{t-1} / Y_{t}-r D_{t-1} / Y_{t}=-g D_{t-1} / Y_{t},
$$

As alternative the medium-term tax gap $\left(t^{*} n-t\right)$ can be taken, where the real interest rate, real economic growth rate and the projected path of no-interest expenditure are taken as given. In this respect, the required tax rate necessary to stabilize the debt/GDP ratio is as follows (Blanchard, 1990):

$$
t_{t}^{*}=\sum(\exp +\operatorname{tr} f) / n+(r-g) D_{0} / Y_{0},
$$

where exp is government expenditure, trf means transfers (both indicator as a ratio to GDP) and $n$ represents the numbers of years over which govexp and trf are incurred,. Nevertheless, equation (7) takes if the values of $n$ and $(r-g)$ are not large. 


\section{Data and Results}

First, we estimate public finance sustainability for V4 economies, Czech Republic (CZE), Hungary (HUN), Poland (POL) and Slovakia (SVK). For short-term examination for the chosen three years: 2004, 2009, 2014. Source all of data were from the AMECO Database. Examination was built on the following key variables:

- the equilibrium level of public debt (D/Y) with nominal data, alternatively, it is assumed for all sampled economies that governments are comfortable tolerating a debt ratio of 60 percent $\left(\mathrm{D} / \mathrm{Y}^{*}\right)$;

- for short-term used the nominal interest rate (i) and

- nominal $\left(\mathrm{g}_{\mathrm{n}}\right)$ growth

The empirical results are summarised below (Tab. 1).

Tab. 1: Short-term fiscal sustainability in V4 countries, 2004, 2009, 2014 (Percentage)

\begin{tabular}{|c|c|c|c|c|c|c|c|c|}
\hline & \multirow[b]{2}{*}{$\begin{array}{l}\text { Public } \\
\text { Debt } \\
\text { (D/Y) }\end{array}$} & \multirow[b]{2}{*}{$\begin{array}{l}\text { Growth } \\
\text { rate of } \\
\text { nominal } \\
\text { GDP }\left(g_{n}\right) \\
\end{array}$} & \multirow[b]{2}{*}{$\begin{array}{l}\text { Nominal } \\
\text { interest } \\
\text { rate (i) }\end{array}$} & \multicolumn{2}{|c|}{$\begin{array}{l}\text { Calculated (short- } \\
\text { term) primary public } \\
\text { balance } \\
\left(\left(\mathbf{i}-\mathrm{g}_{\mathrm{n}}\right) /\left(\mathbf{1}+\mathrm{g}_{\mathrm{n}}\right)\right)^{*}(\mathrm{D} / \mathrm{Y})\end{array}$} & \multirow[b]{2}{*}{$\begin{array}{l}\text { Actual } \\
\text { primary } \\
\text { public } \\
\text { balance } \\
\text { (-b) } \\
\end{array}$} & \multirow[b]{2}{*}{$\begin{array}{l}\begin{array}{l}\text { Diff. } \\
\text { (actual- } \\
\text { calculated } \\
\text { (actual } \\
\text { public debt } \\
\text { assumption) }\end{array} \\
\end{array}$} & \multirow[b]{2}{*}{$\begin{array}{l}\text { Diff. } \\
\text { (actual- } \\
\text { calculated } \\
\text { (targeted } \\
\text { public debt } \\
\text { assumption) } \\
\end{array}$} \\
\hline & & & & $\begin{array}{l}\text { Actual } \\
\text { public } \\
\text { debt } \\
\text { assumpti } \\
\text { on } \\
\end{array}$ & $\begin{array}{l}\text { Targeted } \\
\text { public } \\
\text { debt } \\
\text { assumptio } \\
\text { n }(60 \%) \\
\end{array}$ & & & \\
\hline \multicolumn{9}{|l|}{2004} \\
\hline EU-15 & 62.5 & 4.8 & 4.3 & & & & & \\
\hline CZE & 28.5 & 9.2 & 4.8 & -1.1 & -2.4 & -1.6 & -0.5 & 0.7 \\
\hline HUN & 58.5 & 10.2 & 8.2 & -1.1 & -1.1 & -2.0 & -0.9 & -0.9 \\
\hline POL & 45.3 & 9.6 & 6.9 & -1.1 & -1.5 & -2.4 & -1.3 & -0.9 \\
\hline SVK & 40.6 & 11.3 & 5.0 & -2.3 & -3.4 & -0.2 & 2.1 & 3.2 \\
\hline \multicolumn{9}{|l|}{2009} \\
\hline EU-15 & 75.4 & -5.2 & 3.7 & & & & & \\
\hline CZE & 34.1 & -2.3 & 4.8 & 2.5 & 4.4 & -4.3 & -6.8 & -8.7 \\
\hline HUN & 78.0 & -2.9 & 9.1 & 9.6 & 7.4 & -0.1 & -9.7 & -7.5 \\
\hline POL & 49.8 & 6.6 & 6.1 & -0.2 & -0.3 & -4.8 & -4.6 & -4.6 \\
\hline SVK & 36.0 & -6.6 & 4.7 & 4.4 & 7.3 & -6.4 & -10.8 & -13.7 \\
\hline
\end{tabular}




\begin{tabular}{|c|c|c|c|c|c|c|c|c|}
\hline & \multirow[b]{2}{*}{$\begin{array}{l}\text { Public } \\
\text { Debt } \\
\text { (D/Y) }\end{array}$} & \multirow[b]{2}{*}{$\begin{array}{l}\text { Growth } \\
\text { rate of } \\
\text { nominal } \\
\text { GDP }\left(g_{n}\right) \\
\end{array}$} & \multirow[b]{2}{*}{$\begin{array}{l}\text { Nominal } \\
\text { interest } \\
\text { rate (i) }\end{array}$} & \multicolumn{2}{|c|}{$\begin{array}{l}\text { Calculated (short- } \\
\text { term) primary public } \\
\text { balance } \\
\left(\left(\mathrm{i}-\mathrm{g}_{\mathrm{n}}\right) /\left(1+\mathrm{g}_{\mathrm{n}}\right)\right) *(\mathrm{D} / \mathrm{Y})\end{array}$} & \multirow[b]{2}{*}{$\begin{array}{l}\text { Actual } \\
\text { primary } \\
\text { public } \\
\text { balance } \\
\text { (-b) }\end{array}$} & \multirow[b]{2}{*}{$\begin{array}{l}\text { Diff. } \\
\text { (actual- } \\
\text { calculated } \\
\text { (actual } \\
\text { public debt } \\
\text { assumption) }\end{array}$} & \multirow[b]{2}{*}{$\begin{array}{l}\text { Diff. } \\
\text { (actual- } \\
\text { calculated } \\
\text { (targeted } \\
\text { public debt } \\
\text { assumption) }\end{array}$} \\
\hline & & & & $\begin{array}{l}\text { Actual } \\
\text { public } \\
\text { debt } \\
\text { assumpti } \\
\text { on } \\
\end{array}$ & $\begin{array}{l}\text { Targeted } \\
\text { public } \\
\text { debt } \\
\text { assumptio } \\
\text { n }(60 \%) \\
\end{array}$ & & & \\
\hline \multicolumn{9}{|l|}{2014} \\
\hline EU-15 & 91.8 & 3.0 & 2.0 & & & & & \\
\hline CZE & 42.7 & 4.5 & 1.6 & -1.2 & -1.7 & -0.6 & 0.6 & 1.1 \\
\hline HUN & 76.2 & 7.0 & 4.8 & -1.6 & -1.2 & 1.5 & 3.1 & 2.7 \\
\hline POL & 50.4 & 3.8 & 3.5 & -0.1 & -0.2 & -1.4 & -1.3 & -1.2 \\
\hline SVK & 53.5 & 2.3 & 2.1 & -0.1 & -0.2 & -0.9 & -0.8 & -0.8 \\
\hline
\end{tabular}

Source: AMECO Database and our calculation based on Aristovnik, Berčič, 2007.

In Tab. 1, the first three columns (1-3) show respectively the public debt/GDP ratio, the nominal rate of growth, and the nominal interest rate for V4 and for EU15 than reference. There are used the calculation of sustainable level of primary public balance. Thus, column 4 and 5 show the computation of equation (2). Columns 7 and 8 show the gap between the corresponding calculated (columns 4 and 5) and actual primary fiscal balance (column 6). Since each year's deficit goes to rise the emergent public debt, the higher is the (positive) gap between actual fiscal deficit and hypothetical fiscal deficit, the higher the speed at which the public debt drops (Aristovnik - Berčič, 2007).

In 2004 actual and calculated sustainable fiscal levels seem to be the same in Hungary and Poland. On the other hand, if we take into consideration the targeted public debt (60 percent of GDP), the calculated (permitted) average fiscal deficit is relatively higher and the gap between the actual and the calculated deficit amounts to 0,9 percentage points in Poland and Hungary, but we can see that Czech Republic's and Slovakia's results in actual primary public balance is lower than targeted. The short-term fiscal policy stances of Hungary and Poland seem to be unsustainable.

In 2009, one year after the global financial crises, nominal (and real too) GDP growth of V4 and EU-15 average became negative, except for Poland, because it has a large internal market. If we show real GDP growth rate data in Poland, it is increasing with $2.6 \%$ (AMECO database). Actual and the calculated public debt difference is high and the message that the countries engaged in unsustainable fiscal policies, but expected similar outcome. If we show time series of real and nominal GDP growth, 2009 was the worst year. 
In 2014, five years after the global financial crises, nominal (and real too) GDP growth of V4 and EU-15 average became positive. Public debt was high in EU-15, and Hungary, but the threshold (60 percent of GDP) was not crossed by the Czech Republic, Poland and Slovakia. In this year, the short-term fiscal policy stances of Poland and Slovakia seem to be unsustainable.

\section{Conclusion}

The financial crisis placed budgetary and fiscal policy sustainability on centre stage of researches. Defining the fiscal sustainability is hard, because it depends on the horizon if we can measure many difference indicators. Researchers made and used more difficult models for examination of fiscal sustainability year by year, but newest studies according to the simplest models work best and give accurate forecasting results. This study took this advice and followed a simple intertemporal budget constraint and calculated primary gap in the selected years and testing assumptions for short-term.

During the course of this writing we were examining sustainability of V4 countries, we calculated actual primary gap and compared against real data in short-term, based on Aristovnik - Berčič (2007). The result of the examination is that fiscal stance of V4 countries was varied. In 2004 Hungary and Poland seemed to be unsustainable. We got similar outcomes than Aristovnik - Berčič (2007), who said that the short-term fiscal policy stances of Czech Republic, Hungary and Poland had seemed to be unsustainable.

In 2009, the effects of the global financial crisis in Czech Republic, Hungary and Slovakia too seemed to be unsustainable, except in Poland, where thanks to its large internal market, the fiscal sustainability could be kept. In 2014, the threshold of public debt went under $60 \%$ of GDP in V4 countries except Hungary, but the short-term fiscal policy stance of Poland and Slovakia seemed to be unsustainable. But more importantly the external imbalance problem for Emerging Europe included V4 countries was due to in most cases more one of flows (high current account deficits in the pre-crisis years) rather than large stocks of external debt (Brown - Lane 2011).

Short-term success needs long-term strategies. Our results pointed out that V4 countries need to strengthen budget control in long-run to be able to meet potential growth prospects in the future, as mentioned Kotosz - Peak (2013). Checherita Rother (2010) said about Euroarea countries - although governments of V4 countries should keep this in mind as well - that the policy makers did not let up fiscal consolidation because of being afraid of becoming unpopular with voters, and this attitude would undermine growth prospects and fiscal sustainability too. 


\section{Acknowledgement}

This is paper has been prepared under financial support of Pallas Athéné Domus Scientiae Foundation, which authors gratefully acknowledge. The author would like to thank Árpád Kovács, Gábor Dávid Kiss, Balázs Kotosz and Anita Kéri and three anonymous reviewers for their most useful comments and suggestions.

\section{References}

Alesina, A., Özler, S., Roubini, N., Swagel, P., 1996. Political instability and economic growth. Journal of Economic growth 2, 189-211. DOI: 10.1007/bf00138862.

Aristovnik, A., Berčič, B., 2007. Fiscal sustainability in selected transition countries. Munich Personal RePEc Archive. DOI: 10.2139/ssrn.943506.

Árvai, Zs., Driessen, K., Ötker-Robe, İ., 2009. Regional financial interlinkages and financial contagion within Europe. IMF Working Paper 2009/6. DOI: 10.5089/9781451871531.001.

Barro, R. J., 1979. On the determination of the public debt. The Journal of Political Economy 5, 940-971. DOI: 10.1086/260807.

Barta, Z., 2015. Fiscal sustainability and the welfare state in Europe. ACRN Journal of Finance and Risk Perspectives Special Issue of Social and Sustainable Finance 3, 135-147.

Blanchard, O., Chouraqui, J. C., Hagemann, R. P., Sartor, N., 1990. The sustainability of fiscal policy. New answers to an old question. OECD Economic Studies No. 15.

Blanchard, O. J., 1990. Suggestions for a new set of fiscal indicators, OECD Economics Department Working Papers No. 79. DOI: 10.1787/435618162862.

Bohn, H., 1998. The behavior of U. S. public debt and deficits. Quarterly Journal of Economics 3, 949-963. DOI: 10.1162/003355398555793.

Brown, M., Philip R. Lane, P. R., 2011. Debt overhang in Emerging Europe? Policy Research Working Papers. DOI: 10.1596/1813-9450-5784.

Budina, N., Van Wijnbergen, S., 1997. Fiscal policies in Eastern Europe. Oxford Review of Economic Policy 2, 47-64. DOI: 10.1093/oxrep/13.2.47.

Buiter, W. H., 1985. A guide to public sector debt and deficits. Economic policy 1, 13-61. DOI: $10.2307 / 1344612$.

Burnside, C., 2005. Fiscal sustainability in theory and practice: a handbook. Washington D.C., World Bank Publications. DOI: 10.1596/978-0-8213-5874-0.

Checherita, C., Rother, P., 2010. The impact of high and growing government debt on economic growth. An empirical investigation for the euro area, European Central Bank Working Papers No 1237. 
Cottarreli, C., Moghadam, R., 2011. Modernizing the Framework for Fiscal Policy and Public Debt Sustainability Analysis. International Monetary Fund.

Cruz-Rodríguez, A., 2014. Assessing fiscal sustainability in some selected countries. Theoretical \& Applied Economics 6, 7-22.

Declaration on Cooperation between the Czech and Slovak Federal Republic, the Republic of Poland and the Republic of Hungary in Striving for European Integration (1991)

D'Erasmo, P., Mendoza, E. G., Zhang, J., 2015. What is a Sustainable Public Debt? NBER Working Paper No. 21574. DOI: 10.3386/w21574.

Drudi, F., Prati, A., 2000. Signaling fiscal regime sustainability. European Economic Review 10, 1897-1930. DOI: 10.1016/s0014-2921(99)00035-5.

European Commission, 2006. The long-term sustainability of public finances in the European Union. European Economy No. 4.

European Commission, 2009. Sustainability Report. European Economy No. 9. DOI: $10.2765 / 87726$.

European Commission, 2012. Fiscal Sustainability Report. European Economy No. 8. DOI: $10.2765 / 19669$.

Farkas, B., 2011. The central and eastern european model of capitalism. PostCommunist Economies 1, 15-34. DOI: 10.1080/14631377.2011.546972.

Fatas, A., Mihov, I., 2009. The Euro and fiscal policy. National Bureau of Economic Research Working Paper No. 14722. DOI: 10.3386/w14722.

Hemming, R., MacKenzie, G. A., 1991. Public expenditure and sustainable fiscal policy. In Chu, K., Hemming, R.: Public expenditure handbook. Washington, International Monetary Fund. DOI: 10.5089/9781557752222.071.

IMF, 2000. Transition Economies: An IMF Perspective on Progress and Prospects. IMF, 2002. Assessing Sustainability. Washington, International Monetary Fund.

Kiss G. D., Schuszter T., 2015. The euro crisis and contagion among central and eastern european currencies: recommendations for avoiding lending in a safe haven currency such as CHF. Prague Economic Papers, 6, 1-21. DOI: $10.18267 /$ j.pep.530.

Kotosz, B., Peak, A., 2013. Economic growth and fiscal expenditures in Hungary -Stylized facts based on VAR modelling. Tér-Gazdaság-Ember 3, 55-73.

Kovács, Á., 2014. Fiscal Councils in the Countries of Eastern-Central Europe. Public Finance Quarterly 3, 326-345.

Kovács, Gy., 2009. Financial stability and the banking system, or the imbalance of the intermediary system. Public Finance Quarterly 1, 49-67. 
Mauro, P., Romeu, R., Binder, A., Zaman, A., 2015. A modern history of fiscal prudence and profligacy, Journal of Monetary Economics 76, 55-70. DOI: 10.1016/j.jmoneco.2015.07.003.

McHugh, M. J., Petrova, I., Baldacci, M. E., 2011. Measuring fiscal vulnerability and fiscal stress: a proposed set of indicators. International Monetary Fund Working Paper No. 11/94. DOI: 10.5089/9781455253333.001.

Menguy, S., 2008. A dynamic rule applied to the threshold imposed on the European budgetary deficits. Journal of Policy Modeling 6, 1093-1105. DOI: 10.1016/j.jpolmod.2008.01.003.

Orban, G., Szapary, G., 2004. The Stability and Growth Pact from the perspective of the New Member States. Journal of Policy Modeling 7, 839-864. DOI: 10.1016/j.jpolmod.2004.08.009.

Polito, V., Wickens, M., 2012. A model-based indicator of the fiscal stance. European Economic Review 3, 526-551. DOI: 10.1016/j.euroecorev.2011.12.003.

Roubini, N., Sachs, J.D., 1989. Government spending and budget deficits in the industrialized countries. Economic Policy 8, 99-132. DOI: 10.2307/1344465.

Spaventa, L., 1987. The growth of public debt: Sustainability, fiscal rules, and monetary rules. IMF Staff Papers 2, 374-399. DOI: 10.2307/3867139.

Tanzi, V., 1999. Transition and the changing role of government. Finance and Development 2, 20-23.

Veugelers, R., Mrak, M., 2009. The knowledge economy and catching-up member states of the European Union. Report prepared for Commissioner's Potocnik's Expert Group 'Knowledge for Growth'. European Commission No. 49.

Wyplosz, C., 2007. Debt sustainability assessment the IMF approach and alternatives. Geneva, Graduate Institute of International Studies. 